\title{
DOCKING ANALOG KURKUMIN TURUNAN PIPERAZINDION DENGAN TUBULIN (1TUB) RANTAI $\beta$ MENGGUNAKAN VINA DAN AUTODOCK ${ }^{1}$
}

\author{
Broto Santoso \\ Fakultas Farmasi, Universitas Muhammadiyah Surakarta \\ broto.santoso@gmail.com
}

\begin{abstract}
ABSTRAK
Program Autodock mampu memprediksi energi bebas dan konformasi ikatan antara fleksibel ligan dan makromolekul target yang telah diketahui. Senyawa turunan dan analog kurkumin adalah ligan yang telah banyak dihasilkan dan diuji aktivitasnya. Beberapa diantaranya memiliki khasiat yang lebih baik dari kurkumin. Enam senyawa turunan piperazindion, kurkumin, PGV-0, dan PGV-1 dihitung energi optimasi geometrinya menggunakan density functional theory (DFT) - Gaussian. Ligan hasil optimasi dicari energi ikatan ligan dengan reseptor 1TUB rantai $\beta$ melalui docking menggunakan Vina dan Autodock dengan metode Lamarckian Genetic Algorithm (LGA), traditional Genetic Algorithm (tGA), dan Simulated Annealing (SA) Monte Carlo. Data energi ikatan (affinitas) terbaik yang diperoleh dianalisis dengan Anova: Two-Factor Without Replication $(P=0,01)$. Hasil docking dengan semua metode menunjukkan bahwa senyawa analog kurkumin turunan piperazindion mempunyai potensi ikatan lebih baik dibanding senyawa induknya
\end{abstract}

Kata Kunci: 1TUB, Autodock, docking, kurkumin, piperazindion

\section{ABSTRACT}

Autodock could predict free energy and bonding conformation between flexible ligand and macromolecular of target which has been known earlier. Derivates and analogues of curcumin are ligands have been widely produced and tested for its activity. Some of them have a better efficacy than curcumin. Six molecules of piperazinedione derivates along with curcumin, PGV-0, and PGV1 have been calculated their geometry optimization using Density Functional Theory (DFT) method of Gaussian. Their conformation molecules have been docked to receptor of 1TUB chain $\beta$ to calculate their binding energy using Vina and Autodock with methods of Lamarckian Genetic Algorithm (LGA), traditional Genetic Algorithm (tGA), dan Simulated Annealing (SA) Monte Carlo. The best data of binding energy (affinity) each molecules were analyzed using Anova: Two-Factor Without Replication $(P=0.01)$. The result of all methods of docking calculation show those curcumin analogues: piperazinedione derivates have a better binding potency than curcumin, their lead compound.

Kata Kunci: 1TUB, Autodock, docking, curcumin, piperazinedione

1 Telah dipresentasikan di Konggres IAI XVIII, Makasar, 10 Desember 2010.

\section{PENDAHULUAN}

Desain obat secara rasional menggunakan bantuan komputer mulai membuahkan hasil. Senyawa obat baru hasil rancang obat dapat dihitung aktivitas ikatannya secara komputasi pada protein yang bertanggung jawab terhadap suatu penyakit. Beberapa telah dilaporkan dan diantaranya adalah terhadap HIV-1 protease (protein retrovirus Human Immunodeficiency Virus yang menyebabkan Acquired Immune Deficiency Syndrome atau AIDS), sintase timidilat (antikanker), dan fosforilasa nukleosida purin (gangguan autoimun) telah masuk dalam tahapan uji klinis (Trylska et al., 2007; Kubinyi, 1998; Goodsell et al., 1996; Touroutoglou and Pazdur, 1996) bahkan ada yang sudah mampu dibuat dalam bentuk pemodelan aktivitas ikatan vernakalant (ligan) dengan Kv1,5 channels (protein) (Eldstrom and Fedida, 2009).

Rancangan obat rasional dikembangkan melalui penggunaan komputasi untuk menemukan konformasi ikatan ligan untuk target makromolekul struktur yang telah diketahui. Komputasi merupakan alat untuk menguji dan melakukan urutan peringkat geometri calon obat berdasarkan modifikasi senyawa penuntun atau melakukan skrining database molekul yang tersedia untuk mencari senyawa penuntun baru (Goodsell et al., 1996).

Salah satu program komputasi yang gratis adalah AutoDock yang merupakan program docking otomatis yang dirancang untuk memprediksi energi bebas dan konformasi ikatan antara flexible ligand dan makromolekul target (struktur kimia 3 dimensi) 
yang telah diketahui. Begitu pula dengan Autodock Vina yang merupakan program docking lainnya dengan kemampuan dalam penemuan obat, molecular docking, dan skrining senyawa baru secara virtual (Trott and Olson, 2010; Morris et al., 2009; Goodsell et al., 1996).

Senyawa turunan dan analog kurkumin adalah ligan yang telah banyak dihasilkan dan diuji aktivitasnya. Beberapa diantaranya, Pentagamavunon-0 (2,5-bis-(4-hidroksi-3metoksi)-benzilidin-siklopentanon) dan PGV-1 (2,5-bis-(4-hidroksi-3,5-dimetil)-benzilidin-

siklopentanon), kedua analog ini memiliki potensi aktivitas (terutama anti-kanker sel T47D) yang lebih baik dari kurkumin (Da'i et al., 2007; Reksohadiprodjo et al., 2004).

Kelompok lain analog kurkumin adalah turunan piperazindion. Piperazindion dapat digunakan sebagai pengganti gugus tengah diketon kurkumin dan dengan mempertahankan gugus samping PGV-0 dan PGV-1 diperoleh senyawa turunan piperazindion. Beberapa turunan piperazindion telah diteliti dan memiliki aktivitas inhibisi pertumbuhan sel, sitostatik, dan sitotoksik (Andreani et al., 2008), dan antikanker sporidesmins merupakan turunan piperazin-2,5-dion (Polaske et al., 2009). Pembuktian adanya aktivitas ini dapat dilakukan melalui teknik molecular docking terhadap salah satu protein yang ditenggarai paling banyak berperan dalam siklus sel kanker, yaitu tubulin (Davis et al., 1999). Protein 1TUB dipilih karena dapat mewakili tubulin yang terdapat dalam siklus sel kanker dalam manusia.

\section{METODOLOGI PENELITIAN}

Alat yang digunakan adalah seperangkat

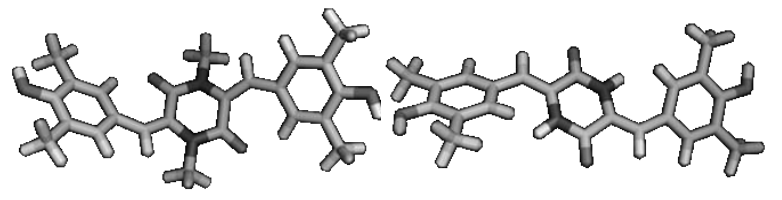

$$
1-(40 m)
$$

$$
\text { 2-(4op) }
$$

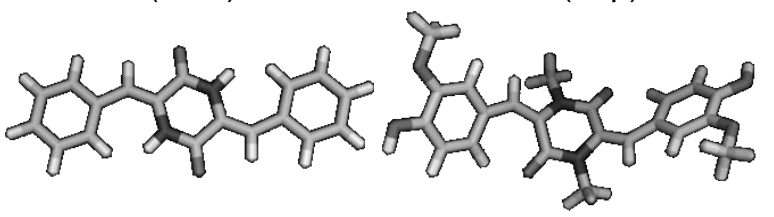

4-(bep)

5-(vam)

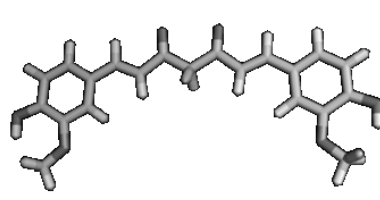

7-(cur)

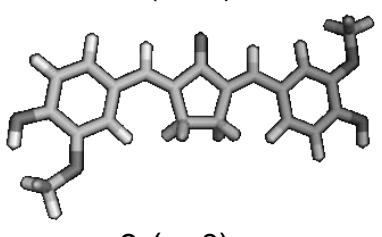

$8-(p g 0)$

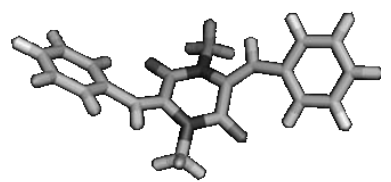

3-(bem)

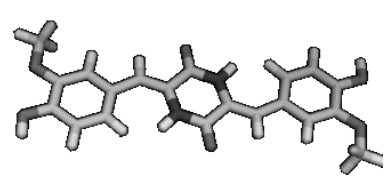

6-(vap)

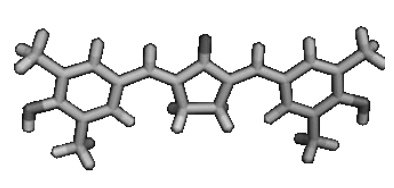

9-(pg1)

Gambar 1- Struktur 3D hasil optimasi geometri menggunakan perhitungan DFT-Gaussian (view in PyMol). 


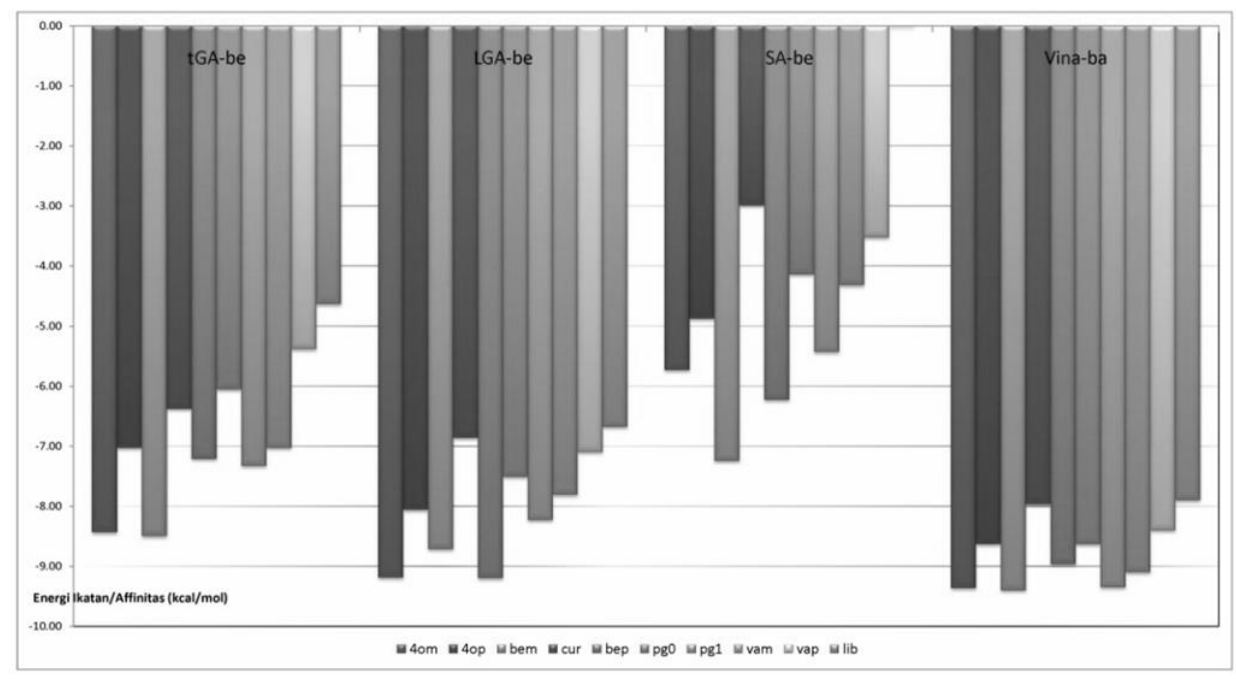

Gambar 2- Energi ikatan $(\mathrm{kcal} / \mathrm{mol})$ docking antara ligand dengan 1TUB rantai $\beta$ (be=binding energy; ba=binding affinity; $\mathrm{n}=6$; turunan piperazindion = 4om, 4op, bem, bep, vam, vap; cur = kurkumin; pg0 = PGV-0; dan pg1 = PGV-1).

\section{Docking analog kurkumin turunan turunan piperazindion: 4om, bem, dan bep piperazindion \\ Docking masing-masing ligand dilakukan dengan 6 kali replikasi perhitungan di setiap metodenya. Hasil yang diperoleh adalah seperti yang ditampilkan pada Gambar 2. Energi ikatan dihitung pada daerah binding site dari memiliki energi ikatan terkuat secara berurutan pada metode Vina (bersama dengan bem dan pg1), tGA-SA, dan LGA. Namun tiga besar molekul yang menunjukkan interaksi ikatan lebih kuat dibandingkan dengan ligan lainnya adalah 4om, bem, bep dan pg1 (Gambar 2).} Taxotere. Data hasil memperlihatkan bahwa
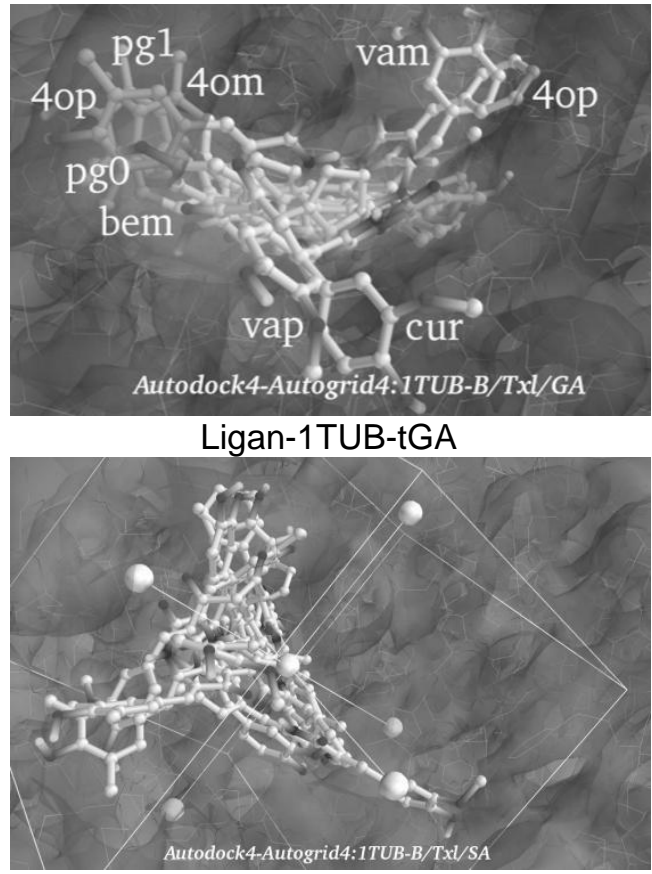

Ligan-1TUB-SA
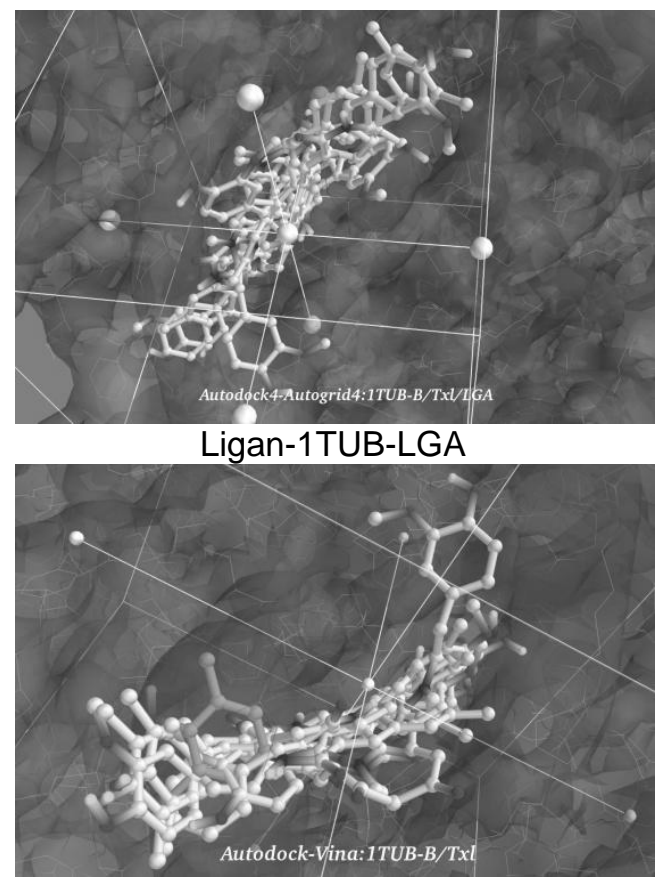

Ligan-1TUB-Vina

Gambar 3- Interaksi semua ligand dengan 1TUB rantai $\beta$. Docking dilakukan menggunakan metode Vina dan Autodock metode Lamarckian Genetic Algorithm (LGA), traditional Genetic Algorithm (tGA), dan Simulated Annealing (SA) Monte Carlo. Semua ligan berinteraksi pada pocket binding site dari Taxotere.

Hal lain yang menarik adalah hasil docking juga menunjukkan bahwa secara keseluruhan PGV0 dan PGV-1 memiliki energi ikatan yang lebih kuat dibandingkan dengan kurkumin.
Perbandingan hasil docking antara PGV-0 dan PGV-1 dengan kurkumin sama dengan hasil penelitian yang telah dilakukan Da'i et al. (2007), yaitu kedua analog kurkumin tersebut 
memiliki aktivitas anti-kanker yang lebih baik terhadap protein tubulin.

Gambar 3 memperlihatkan bahwa semua konformasi molekul hasil docking berbagai metode masih berada di dalam binding pocket dari molekul ligan hasil kristalografi, yaitu Taxotere. Hal ini membuktikan bahwa Vina dan Autodock selektif dalam melakukan perhitungan komputasi walaupun gridbox yang digunakan adalah seluruh molecular space dari protein target.

\section{Analisis Data}

Data docking berupa energi ikatan (kcal/mol) ligan dengan 1TUB rantai $\beta$ dihitung dengan ANOVA: Two-Factor Without Replication (faktor ligan dan metode) diperoleh hasil bahwa setiap metode memiliki hasil yang berbeda nyata untuk masing-masing ligand dan nilai energi ikatan setiap ligand berbeda nyata satu dengan ligand lainnya dalam metode docking yang sama $(P=0,01)$.

\section{KESIMPULAN}

Turunan piperazindion (4om, bem dan bep) yang merupakan analog dari kurkumin memiliki potensi aktivitas yang lebih baik dibandingkan kurkumin dalam hal interaksinya dengan protein tubulin melalui perhitungan docking.

\section{UCAPAN TERIMA KASIH}

Penulis ucapkan terima kasih kepada Fakultas Farmasi UMS atas dukungannya dalam penyelesaian penelitian ini.

\section{DAFTAR PUSTAKA}

Andreani, A., Burnelli, S., Granaiola, M., Leoni, A., Locatelli, A., Morigi, R., Rambaldi, M., Varoli, L., Landi, L., Prata, C., Berridge, M. V., Grasso, C., Fiebig, H.-H. dan Kelter, G., 2008, "Antitumor Activity of Bis-indole Derivatives(1)." Journal of Medicinal Chemistry, 51 (15): 4563-4570.

Da'i, M., Edy Meiyanto, E., Supardjan, Jenie, U.A., dan Kawaichi, M., 2007, Potensi Antiproliferative Analog Kurkumin Pentagamavunon terhadap Sel Kanker Payudara T47D, Artocarpus, 7 (1): 14-20.

Davis, A., Jiang, J.D., Middleton, K.M., Wang, Y., Weisz, I., Ling, Y.H., and Bekesi, J.G., 1999, Novel Suicide Ligands of Tubulin Arrest Cancer Cells in S-Phase, Neoplasma, 1 (6): 498 - 507

Eldstrom, J. and Fedida, D., 2009, Modeling of high-affinity binding of the novel atrial antiarrhythmic agent, vernakalant, to Kv1.5 channels, Journal of Molecular Graphics and Modelling, 28: 226-235.

Frisch, M. J., Trucks, G. W., Schlegel, H. B., Scuseria, G. E., Robb, M. A., Cheeseman, J. R., Montgomery, Jr., J. A., Vreven, T., Kudin, K. N., Burant, J. C., Millam, J. M., lyengar, S. S., Tomasi, J., Barone, V., Mennucci, B., Cossi, M., Scalmani, G., Rega, N., Petersson, G. A., Nakatsuji, H., Hada, M., Ehara, M., Toyota, K., Fukuda, R., Hasegawa, J., Ishida, M., T. Nakajima, Y. Honda, O. Kitao, H. Nakai, M. Klene, X. Li, J. E. Knox, H. P. Hratchian, J. B. Cross, V. Bakken, C. Adamo, J. Jaramillo, R. Gomperts, R. E. Stratmann, O. Yazyev, A. J. Austin, R. Cammi, C. Pomelli, J. W. Ochterski, P. Y. Ayala, K. Morokuma, G. A. Voth, P. Salvador, J. J. Dannenberg, V. G. Zakrzewski, S. Dapprich, A. D. Daniels, M. C. Strain, O. Farkas, D. K. Malick, A. D. Rabuck, K. Raghavachari, J. B. Foresman, J. V. Ortiz, Q. Cui, A. G. Baboul, S. Clifford, J. Cioslowski, B. B. Stefanov, G. Liu, A. Liashenko, P. Piskorz, I. Komaromi, R. L. Martin, D. J. Fox, T. Keith, M. A. Al-Laham, C. Y. Peng, A. Nanayakkara, M. Challacombe, P. M. W. Gill, B. Johnson, W. Chen, M. W. Wong, C. Gonzalez, and J. A. Pople, 2004, Gaussian 03 - Revision E.01, Gaussian, Inc., Wallingford CT, www.gaussian.com.

Goodsell, D.S., Morris, G.M., and Olson, A.J., 1996, Automated Docking of Flexible Ligands: Applications of AutoDock, Journal of Molecular Recognition, 9: 1-5.

Kubinyi, H., 1998, Structure-based Design of Enzyme Inhibitors and Receptor Ligands, Current Opinion in Drug Discovery and Development, 1 (1): 4-15.

Morris, G.M., Huey, R., Pique, M., Hart, W.E., Halliday, R.S., Lindstrom, W., Chang, M., Gillet, A., Forli, S., Belew, R.K., Goodsell, D.S., and Olson, A.J., 2009, AutoDock 4.2 -Release 4.2.3, The Scripps Research Institute. 
Polaske, N. W., Nichol, G. S. dan Olenyuk, B., 2009, "Polymorphism and phase transition behavior of $\quad 6,6^{\prime}$-bis(chloromethyl)-1,1',4,4'-tetramethyl-3,3'-(-phenylenedimethylene)bis(piperazine-2,5dione)." Acta Crystallographica Section C, 65 (8): 0381-0384.

Reksohadiprodjo, M. S., Timmerman, H., Sardjiman, Margono, S. A., Martono, S., Sugiyanto, Hakim, L. R., Nurlaila, Hakim, A. R., Puspitasari, I., Nurrochmad, A., Purwantiningsih, Oetari, R. A. dan Yuwono, T., 2004, Derivatives of Benzylidene Cyclohexanone,Benzylidene Cyclopentanone, and Benzylidene Acetone, and Therapeutic Uses Thereof, United States Patent, USA, US006777447B2: 1-12.

Touroutoglou, N., and Pazdur, R., 1996, Minireview: Thymidylate Synthase Inhibitors, Clinical Cancer Research, 2: 227-243.

Trott, O., and Olson, A. J., 2010, AutoDock Vina: improving the speed and accuracy of docking with a new scoring function, efficient optimization and multithreading, Journal of Computational Chemistry, 31: 455-461.

Trylska, J., Tozzini, V., Chang, C.A., and McCammon, J.A., 2007, HIV-1 Protease Substrate Binding and Product Release Pathways Explored with Coarse-Grained Molecular Dynamics, Biophysical Journal, 92: 4179-4187.

Wolf, L.K., 2009, New software and Websites for the Chemical Enterprise, Chemical and Engineering News,87:31. 